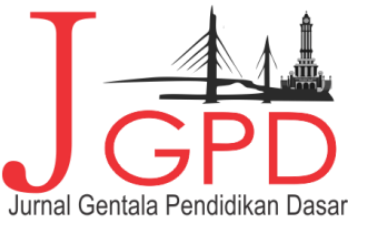

Artikel Penelitian

\section{JURNAL GENTALA PENDIDIKAN DASAR VDl.5 No. I Juni 2020, Halaman I-II \\ P-ISSN : 2614-7092, E-ISSN : 2621-961I}

Terbit Online Pada Laman Web : hittp://online-journal.unja.ac.id/index.php/gentala email : penyunting.jurnal.g-pgsd回unja.ac.id

\title{
Pengaruh Pengetahuan Pengelolaan Sampah Di Sekolah Terhadap Sikap Peduli Lingkungan Siswa Di SDN Batan Indah
}

Dika Cipta Raharjo ${ }^{1}$, Apri Utami Parta Santi ${ }^{2}$

${ }^{1,2)}$ Pendidikan Guru Sekolah Dasar, Fakultas Ilmu Pendidikan, Universitas Muhammadiyah Jakarta, Jl. Kh Ahmad Dahlan, Cirendeu, Tangerang Selatan, 15419

\begin{tabular}{ll}
\hline Informasi Artikel & ABSTRAK \\
Ditinjau : 7 Feb 2020 & $\begin{array}{l}\text { Penelitian ini dilatar belakangi oleh rendahnya pemahaman siswa } \\
\text { Direvisi : 18 Maret 2020 }\end{array}$ \\
Terbit Online : 1 Juni 2020 & $\begin{array}{l}\text { Metode penelitian yang digunakan adalah metode kuantitatif } \\
\text { dengan pendekatan survey dengan menggunakan tes pilihan ganda }\end{array}$ \\
& (PG) sebanyak 31 pertanyaan untuk pengetahuan pengelolaan \\
& sampah dan angket sebanyak 20 pernyataan untuk sikap peduli \\
Kata Kunci & lingkungan. Populasi yang digunakan dalam penelitian ini adalah \\
Pengetahuan & siswa kelas V SDN Batan Indah yang berjumlah 121 siswa. \\
Pengelolaan & Pengambilan sampel menggunakan teknik simple random \\
Sampah,Sikap Peduli & sampling, dengan menggunakan besaran rumus slovin sebesar 5\% \\
Lingkungan & dan didapati sampel sebanyak 93 siswa dari 3 kelas A,B dan C. \\
\hline Korespondensi & Analisis data menggunakan korelasi dan koefisien determinasi, \\
e-mail : & diperoleh nilai r- Hitung sebesar 0,581 dan R Square 33,7\%. Hal ini \\
Dikacipta264@gmail.com & menunjukan adanya pengaruh pengetahuan pengelolaan sampah di \\
& sekolah terhadap sikap peduli lingkungan siswa di SDN Batan \\
& Indah.
\end{tabular}

DOI : https://doi.org/10.22437/gentala.v5i1.9041

\section{PENDAHULUAN}

Pendidikan merupakan pengaruh lingkungan atas individu untuk menghasilkan perubahan-perubahan yang tetap di dalam kebiasaan-kebiasaan, pemikiran, sikap dan tingkah laku. Pendidikan juga adalah pembelajaran pengetahuan, keterampilan, dan kebiasaan sekelompok orang yang di turunkan dari satu generasi ke generasi berikutnya melalui pengajaran, pelatihan atau penelitian.

Pengetahuan pengolahan sampah di Indonesia umumnya masih terbilang tradisional. ini seringkali akhirnya berubah menjadi praktek pembuangan sampah secara sembarangan tanpa mengikuti ketentuan teknis di lokasi yang sudah ditentukan. Pengelolaan sampah saat ini berdasarkan UU No. 18 Tahun 2008 dan PP No. 81 Tahun 2012, di lakukan dengan dua fokus utama yakni pengurangan dan penanganan sampah (Widodo, 2009: 329). 


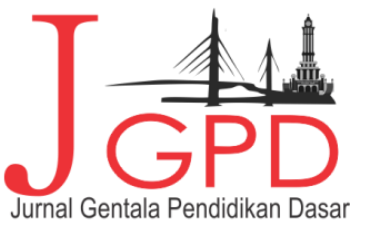

JURNAL geNTALA PENDIDIKAN DASAR VD.5 No. I Juni 2020, Halaman I-II

P-ISSN : 2614-7D92, E-ISSN : 2621-96II

Terbit Online Pada Laman Web : hittp://online-journal.unja.ac.id/index.php/gentala email : penyunting.jurnal.g-pgsd国unja.ac.id

Menurut perkiraan Badan Pusat Statistik (BPS) dalam Simanjorang (2014: 36), pada tahun 2020 di 384 kota di Indonesia mencapai 80.235,87 ton tiap hari. Dari sampah yang dihasilkan tersebut diperkirakan sebesar 4,2\% akan di angkut ke Tempat Pembuangan Akhir (TPA), sebanyak 37, 6\% dibakar, di buang ke sungai sebesar 4,9\% dan tidak tertangani sebanyak $53,5 \%$.

Kota Tangerang Selatan sangat berpotensi untuk menjadi salah satu daerah yang maju, yaitu laju pertumbuhan ekonomi yang tinggi yang berasal dari kontribusi sumber-sumber pendapatan terutama pajak dan retribusi, penyediaan pemukiman/perumahan. Kepadatan penduduk secara tidak langsung menjadi faktor utama permasalahan sampah yang berdampak pada meningkatnya produksi sampah di wilayah Tangerang Selatan.

Permasalahan sampah di wilayah Kota Tangerang Selatan merupakan residu atau sisasisa peninggalan masa Pemerintahan Kabupaten Tangerang. Karena begitu luasnya wilayah Kabupaten Tangerang saat itu, sehingga cakupan pelayanan yang bersifat teknis kewilayahan menjadi kurang optimal. Kemudian puncak permasalahan sampah yang sebenarnya terjadi tahun 2010 pada awal berdirinya Kota Tangerang Selatan.

Bupati Tangerang secara sepihak menarik seluruh armada penarik sampah. Akibatnya sampah yang seharusnya dapat diangkut dalam satu hari menjadi tertunda sehingga terjadi penumpukan sampah di tempat-tempat umum. Akhirnya, Pemerintah Kota Tangerang Selatan saat itu melakukan kebijakan sewa armada pengangkut sampah. Walaupun secara jumlah kapasitas armada sewa yang ada masih sangat jauh dari mencukupi, namun secara perlahan sampah-sampah yang menumpuk dapat di urai (Oktaviani, $2016: 1$ )

Data Dinas Kebersihan Pertamanan dan Pemakaman (DKPP) Tangerang Selatan 2010 Jumlah penduduk di kota Tangerang Selatan mencapai 1.303.569 jiwa, timbulan sampah per hari kota Tangerang Selatan sekitar 3.919 m3/hari. Jumlah penduduk di kota Tangerang Selatan mencapai 1.303.569 jiwa, timbulan sampah per hari kota Tangerang Selatan sekitar 3.919 m3/hari. (Srisantyorin, 2018: 66)

Harus diakui bahwa kecenderungan masyarakat secara umum tidak terlalu peduli memberikan perlakuan yang baik dan benar terhadap sampah yang mereka hasilkan, alih-alih sikap warga masyarakatnya belum semua mematuhi peraturan tentang menjaga kebersihan. Peneliti amati masih banyak warga masyarakat Tangerang Selatan yang membuang sampah sembarangan, seperti membuang sampah di pinggir jalan, saluran irigasi air, dan ke sungai. 


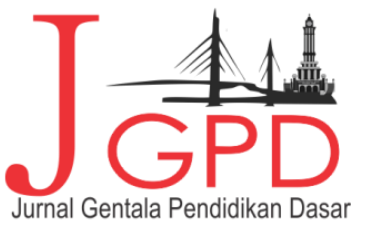

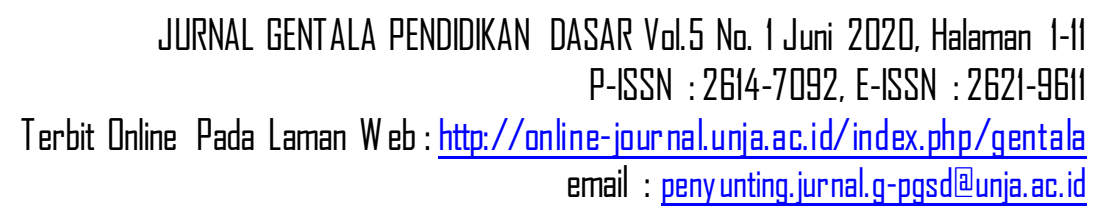

Pengetahuan merupakan hasil dari suatu praktek, baik praktek yang secara langsung maupun praktek tidak langsung. Menurut Prawironegoro dalam Lestari (2018: 10), mengatakan bahwa praktek tidak langsung merupakan pengalaman orang lain yang di jadikan sebagai pengetahuan, sedangkan praktek langsung menimbulkan pengetahuan yang langsung di peroleh.

Menurut Arikunto dalam Boedijono (2019: 11), arti pengelolaan menurut konsep dan teori dapat diartikan dengan manajemen, pengaturan atau pengurusan. Sejalan dengan yang dikemukakan oleh Arikunto, Rohani dalam Daini (2017: 239-240), pengelolaaan adalah upaya untuk mengatur aktivitas berdasarkan konsep dan prinsif yang lebih efektif, efisien dan produktif dengan diawali penentuan strategi dan perencanaan.

Tchobanoglous dalam Soma (2010: 11), mengatakan secara definisi, sampah adalah semua jenis bahan buangan baik yang berasal dari manusia atau binatang yang biasanya berbentuk padat. Umumnya bahan-bahan tersebut dibuang karena dirasakan oleh pemiliknya barang yang tidak berharga, tidak bernilai, dan tidak diinginkan. Jadi, segala bahan buangan yang biasanya berbentuk padat, tidak berharga, tidak bernilai, dan tidak diinginkan dapat dikategorikan sebagai sampah. Sejalan dengan Tchobanougllous dalam Soma Menurut Kes (2016: 61), sampah didefinisikan sebagai suatu benda yang tidak digunakan atau tidak dikehendaki dan harus dibuang, yang di hasilkan oleh kegiatan-kegiatan manusia. Sejalan dengan yang dikemukakan oleh Kes, Sejati dalam Soma (2010: 1), mengatakan sampah dalam hal ini berupa bahan-bahan padat yang tidak berharga, tidak dikehendaki, sehingga dibuang oleh pemiliknya.

Menurut Hadiwiyoto dalam Sejati (2009: 13), mengatakan ada beberapa macam penggolongan sampah. Penggolongan ini dapat didasarkan atas beberapa kriteria, yaitu : asal, komposisi, bentuk, lokasi, proses terjadinya, sifat, dan jenisnya. Sejalan yang dikatakan oleh Hadiwiyoto, Menurut Sejati (2009: 15) mengatakan secara garis besar penggolongan sampah terbagi menjadi tiga :

1) Sampah organik / basah.

Sampah basah adalah sampah yang berasal dari makhluk hidup, seperti daun-daunan, sampah dapur, sampah restoran, sisa sayuran, sisa buah. Sampah jenis ini dapat terdegradasi (membusuk/hancur) secara alami.

2) Sampah anorganik / kering. 

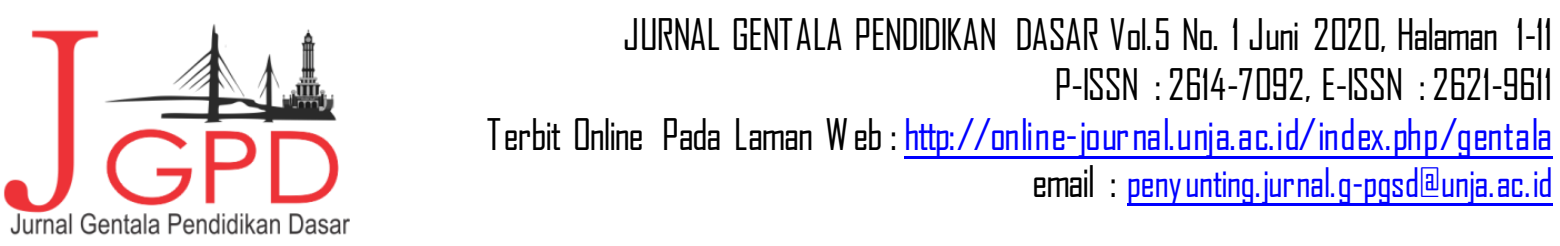

Sampah kering adalah sampah adalah sampah yang tidak dapat terdegradasi secara alami. Contohnya: logam, besi, kaleng, plastik, karet, botol, dan lain-lain.

3) Sampah berbahaya

Sampah jenis ini berbahaya bagi manusia. Contohnya : baterai, jarum suntik bekas, limbah racun kimia, limbah nuklir, dan lain-lain. Sampah jenis ini memerlukan penanganan khusus.

Menurut Kes (2016: 61-62), menjelaskan pengelompokan sampah secara umum, hanya benda-benda padat :

1) Sampah yang mudah membusuk (garbage)

Misalnya sisa makanan

2) Sampah yang tidak membusuk (rubbish) terdiri dari :

3) Sampah yang mudah terbakar, misalnya kertas,kayu.

4) Sampah yang tidak mudah terbakar, misalnya kaca, kaleng.

5) Sampah berupa abu hasil pembakaran (ashes)

Misalnya pembakaran kayu, batu bata, arang.

6) Sampah padat hasil industri (industrial waste)

Misalnya potongan besi, kaleng, kaca.

7) Sampah padat yang berserakan di jalan-jalan (street sweeping), yaitu sampah yang dibuang oleh penumpang atau pengemudi kendaraan bermotor.

Menurut Sejati (2009: 21), pengelolaan sampah adalah semua kegiatan yang dilakukan untuk menangani sampah sejak ditimbulkan sampai dengan pembuangan akhir. Secara garis besar, kegiatan pengelolaan sampah meliputi pengendalian timbulan sampah, pengumpulan sampah, transfer dan transport, pengelolaan, dan pembuangan akhir. Sejalan dengan yang disampaikan oleh Sejati, menurut Tchobanoglous dalam Soma (2010: 1), pengelolaan sampah adalah sebuah upaya komprehensif menangani sampah-sampah yang dihasilkan dari berbagai aktivitas manusia, di kelompokan menjadi enam elemen terpisah yaitu, pengendalian bangkitan (control of generation), penyimpanan (storage), pengumpulan (collection), pemindahan, pengangkutan (transfer and transport), pemrosesan (processing), dan yaitu pembuangan (disposal).

Menurut Siregar (2018: 41), sikap (Attitude) merupakan evaluasi, perasaan, dan kecenderungan seseorang yang secara konsisten menyukai atau tidak menyukai suatu objek 


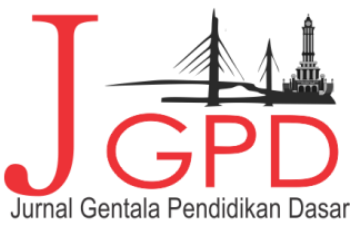

JURNAL GENTALA PENDIDIKAN DASAR Vol.5 No. I Juni 2020, Halaman I-II

P-ISSN : 2614-7092, E-ISSN : 2621-96il

Terbit Online Pada Laman W eb : http://unline-juurnal.unja.ac.id/index.php/gentala email : peny unting.jurnal.g-pgsd国unja.ac.id

atau gagasan. Sejalan dengan yang disampaikan Siregar Menurut Djaali dalam Rizkiyah (2019: 62), sikap adalah kecenderungan untuk bertindak berkenaan dengan objek tertentu.

Mundiatun dalam Chan (2019: 191), menjelaskan bahwa lingkungan merupakan pemukiman tempat hidup dan segala keadaan serta kondisi yang ada di dalamnya yang secara langsung atau tidak langsung dapat mempengaruhi tingkat kehidupan.

Daryanto dalam Narut (2019: 260), peduli lingkungan merupakan sikap dan tindakan yang selalu berupaya mencegah kerusakan pada lingkungan alam di sekitarnya, dan mengembangkan upaya-upaya untuk memperbaiki kerusakan alam yang sudah terjadi. Sejalan dengan yang disampaikan oleh Daryanto, zuchdi dalam Narut (2019: 261), menjelaskan, peduli lingkungan adalah sikap dan tindakan yang selalu berupaya mencegah kerusakan pada lingkungan alam di sekitarnya, dan mengembangkan upaya-upaya untuk memperbaiki kerusakan alam yang sudah terjadi.

Menurut Nenggala dalam Taufiq (2014: 141), seseorang yang peduli lingkungan yaitu : 1) selalu menjaga kelestarian lingkungan sekitar, 2) tidak mengambil, menebang, tidak mencabut tumbuh-tumbuhan yang terdapat di sepanjang jalanan, 3) Tidak mencoret-coret, menorehkan tulisan pada pohon, batu-batu, jalan atau dinding, 4) selalu membuang sampah pada tempatnya, 5) tidak membakar sampah disekitar perumahan, 6) melaksanakan kegiatan membersihkan lingkungan, 7) menimbun barang-barang bekas, 8) membersihkan sampahsampah yang menyumbat saluran air.

Menurut Yusuf dalam Hidayat (2017: 10), mengemukakan lingkungan perkembangan yang dapat dipengaruhi perkembangan fisik dan sosial yaitu: lingkungan keluarga, lingkungan sekolah, kelompok teman sebaya atau bermain, dan lingkungan masyarakat.

\section{METODE PENELITIAN}

Penelitian ini dilakukan di kelas V SDN Batan Indah yang Penelitian ini dilakukan di Sekolah Negeri Batan Indah yang beralamat di Jl. Raya Puspitek Serpong Komplek Batan Indah Rt.04/04, Desa Kedemangan Kecamatan, Setu Kota Tangerang Selatan Provinsi Banten. Waktu penelitian ini berlangsung pada semester genap tahun ajaran 20119-2020. Dimulai pada bulan maret sampai dengan bulan april 2020. Penelitian ini menggunakan metode survey dengan pendekatan kuantitatif dan menggunakan teknik analisis regresi linear sederhana. 


\section{Table. 1 Desain Penelitian Paradigma Sede rhana}

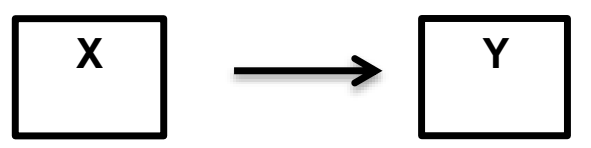

Dimana :

$$
\begin{array}{ll}
\text { X } & \text { : pengetahuan Pengelolaan Sampah } \\
\text { Y } & \text { : Sikap Peduli Lingkungan } \\
& \text { : Pengaruh Variabel X terhadap Variabel Y }
\end{array}
$$

Teknik pengambilan sampel dalam penelitian ini menggunakan teknik simple random sampling. Menurut Sugiyono (2018: 82) simple random sampling adalah dikatakan simple (sederhana) karena pengambilan anggota sampel dari populasi dilakukan secara acak tanpa memperhatikan strata yang ada dalam populasi itu. Pada penelitian ini peneliti mengambil sample kelas $\mathrm{V}$ yang berjumlah 121 terdiri dari kelas $\mathrm{A}, \mathrm{B}$ dan $\mathrm{C}$. Peneliti menggunakan rumus Slovin tingkat kesalahan sebesar 5\% sehingga populasi awal sebanyak 121 siswa menjadi 93 siswa sampel nya.

Teknik pengumpulan data yang di gunakan peneliti adalah observasi, tes pilihan ganda (PG), angket dan dokumentasi. Tes akan di isi oles siswa, digunakan untuk mengetahui pengetahuan siswa tentang pengetahuan pemgelolaan sampah di sekolah, dan angket di isi oleh siswa, di gunakan untuk mengetahui tanggapan siswa mengenai sikap peduli lingkungan. Data yang terkumpul dianalisis dengan menggunakan perhitungan kuantitatif deskriptif, untuk mengetahui hasi pengetahuan sampah di sekolah terhadap sikap peduli lingkungan akan dianalisis dengan menggunakan model skala likert. Adapun untuk uji hipotesis, aanlisis yang di gunakan adalah uji regresi linear sederhana dengan taraf signifikasi $5 \%$ atau 0,05. Berikut adalah gambar kriteria skor tes dan angket pengetahuan pengelolaaan sampah di sekolah terhadap sikap peduli lingkungan menggunakan skala likert

Tingkat populasi dalam penelitian atau tingkat kesalahan pada penelitian ini adalah 0,05 (5\%) dan tingkat kepercayan penelitian ini adalah 95\%. Dengan jumlah populasi dalam penelitian ini sebanyak 121. Dari hasil perhitungan rumus Slovin diperoleh sampel sebanyak 93 responden yang akan digunakan dalam pengolahan data. Cara pengambilan sampel dengan menggunakan simple random sampling untuk mengisi kuesioner Tes berupa pilihan ganda (PG) pada variabel X. Dan pada variabel Y menggunakan (Angket). 


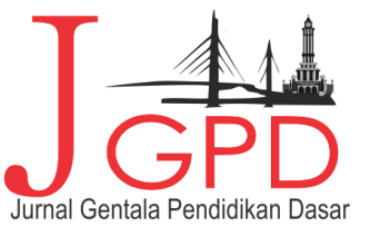

JURNAL GENTALA PENDIDIKAN DASAR Vol.5 No. I Juni 2020, Halaman I-II

P-ISSN : 2614-7092, E-ISSN : 2621-96il

Terbit Online Pada Laman W eb : http://unline-juurnal.unja.ac.id/index.php/gentala email : peny unting.jurnal.g-pgsd国unja.ac.id

\section{HASIL PENELITIAN DAN PEMBAHASAN}

\section{Dis tribusi variabel $\mathbf{X}$ (pengetahuan pengelolaan sampah di sekolah)}

Berdasarkan perhitungan deskripsi data pengetahuan pengelolaan sampah di sekolah maka diperoleh data 93 dengan jumlah 2318, nilai rata-rata (mean) 24,92, nilai tengah (median) 29,00, nilai terbanyak (mode) 31, standar deviasi atau simpangan baku sebesar 9,152, dan varian sebesar 83,766. Selanjutnya diperoleh nilai minimum sebesar 1, dan nilai maksimum sebesar 31

\section{Dis tribusi variabel Y (sikap peduli lingkungan)}

Berdasarkan perhitungan deskripsi data sikap peduli lingkungan maka diperoleh dengan jumlah 7397, nilai rata-rata (mean) 79,54, nilai tengah (median) 81.00,nilai terbanyak (mode) 76, standar devisiasi atau simpangan baku sebesar 11,841, dengan varian sebesar 140,208. Selanjutnya diperoleh nilai minimum sebesar 45 dan nilai maksimum sebesar 100 .

\section{Uji validitas kedua pengaruh pengetahuan pengelolaan sampah di sekolah terhadap sikap peduli lingkungan sis wa SDN Batan Indah}

Hasil uji validitas pada variabel X (pengetahuan pengelolaan sampah di sekolah) dan variabel Y (sikap peduli lingkungan siswa) yang diuji coba di SDN Batan Indah dengan jumlah responden 93 orang dan total item pertanyaan sejumlah 51 dengan $\boldsymbol{r}_{\boldsymbol{t a b e l}} 5 \%$ adalah 0,2039 dikatakan valid jika r-hitung>r-tabel. Hasil uji coba kuesioner berupa tes (PG) variabel X (pengetahuan pengelolaan sampah di sekolah) dan uji coba kuesioner variabel Y (sikap peduli lingkungan). Dapat dikatakan semua tes berupa pilihan ganda (PG) dan kuesioner angket dikatakan valid.

\section{Uji Reliabilitas}

Adapun uji reabilitas yakni derajat kepercayaan yang diperoleh dari hasil angket dan tes sebagai metode pengumpulan data yakni menggunakan kriteria 0,05 maka disebut reliabel. Berdasarkan perhitungan dengan rumus alpha cronbach menggunakan program SPSS.V. 21.0

Berdasarkan output uji reliabilitas tes pilihan ganda (PG) menggunakan Cronbach's alpha memperoleh nilai 0,974 lebih besar dari 0,2039 (0,974>0,2039) maka seluruh item kuesioner dinyatakan reliabel. 


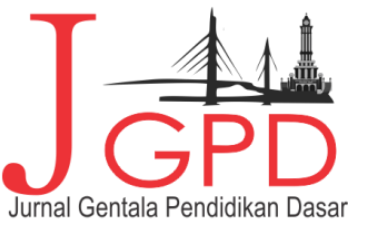

JURNAL GENT ALA PENDIDIKAN DASAR Vol.5 No. I Juni 2020, Halaman 1--II

P-ISSN : 2614-7D92, E-ISSN : 2621-961I

Terbit Online Pada Laman Web : hittp://online-journal.unja.ac.id/index.php/gentala email : penyunting.jurnal.g-pgsd国unja.ac.id

Berdasarkan output uji reliabilitas kuesioner berupa angket menggunakan Cronbach's alpha memperoleh nilai 0,886 lebih besar dari $0,2038(0,886>0,2039)$ maka seluruh item kuesioner dinyatakan reliabel.

\section{Uji Prasyarat Analisis}

\section{a. Uji Normalitas}

Berdasarkan hasil output di atas uji normalitas menggunakan Kolmogorov-Smirnov memperoleh nilai $\mathrm{p}$ value sig seluruh variabel 0,750 lebih besar dari $0,005(0,750>0,05)$ pengambilan keputusan nilai signifikansi memperoleh nilai yang lebih besar dari 0,05 sehingga $\mathrm{H}_{1}$ diterima.

maka dapat di simpulkan bahwa nilai residual berdistribusi normal.

\section{b. Uji Linearitas}

Berdasarkan uji linear yang telah dilakukan, pengaruh pengetahuan pengelolaan sampah di sekolah terhadap sikap peduli lingkungan adalah menghasilkankan nilai $\mathrm{F}$ $=54.693$ dengan signifikasi $=0,000$ dikatakan bahwa ada hubungan tidak linear antara variabel $\mathrm{X}$ dan variabel $\mathrm{Y}$. dikatakan tidak adanya hubungan linear karena nilai signifikasi >0,05 yaitu 0,000. Maka dapat disimpulkan hubungan antara kedua variabel tersebut adalah tidak linear.

Berdasarkan hasil uji validitas dari total 35 soal pilihan ganda dan 25 kuesioner (angket) yang di sebar. Dengan dasar berdasarkan pengambilan keputusan r-hitung > rtabel dengan jumlah $\mathrm{r}$-tabel 0,218 berdasarkan jumlah $\mathrm{n}$ yaitu 81 responden. Terdapat 51 soal yang valid dan 9 soal yang tidak valid. Selanjutnya peneliti melakukan uji realibilitas dengan menggunakan SPSS. V. 21.0, dengan rumus alpha cronbach dan mendapatkan nilai alpha sebesar 0,974 untuk variabel X ( pengetahuan pengelolaan sampah) dan mendapatkan nilai alpha sebesar 0,886 untuk variabel $\mathrm{Y}$ (sikap peduli lingkungan), dimana hasil alpha > r- table yaitu 0,2039. Itu berarti tes dan kuesioner angket yang diujikan dapat dikatakan reliabel.

Berdasarkan uji normalitas one Kolmogorov-smomov dengan unstaddardized residual menunjukan bahwa variabel $\mathrm{X}$ dan $\mathrm{Y}$ berdistribusi normal hal ini terbukti dengan variabel $\mathrm{X}$ dan $\mathrm{Y}$ di peroleh nilai 0,750 sehingga $r$-hitung > r-tabel 0,05 yang berarti kedua data tersebut berdistribusi normal. 


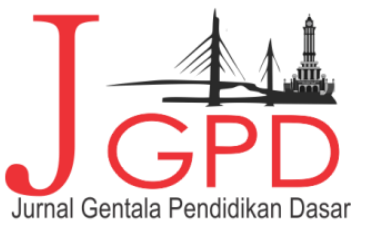

JURNAL GENTALA PENDIDIKAN DASAR Val.5 No. I Juni 2020, Halaman I-II

P-ISSN : 2614-7092, E-ISSN : 2621-9611

Terbit Online Pada Laman Web : http://online-juurnal.unja.ac.id/index.php/gentala email : penyunting.jurnal.g-pgsd回unja.ac.id

Persamaan regresi $Y=60,812+0,751 X$ sedangkan nilai t-hitung $=6,804$ dengan nilai signifikasi $0,000<0,05$. Maka hal ini berarti ada pengaruh yang signifikan antara variabel independen $(\mathrm{X})$ dan variabel dependen $(\mathrm{Y})$.

Angka yang dihasilkan dari rumus korelasi juga diolah kembali dengan rumus pengujian determinasi, dan sebagai hasilnya diperoleh nilai koefisien determinasi sebesar 33,7\%. Dan sisanya di pengaruhi oleh wawasan dan kesadaran, tingkat pendidikan, malas mencari atau berjalan menuju arah tempat sampah, pemahaman dari guru, keluarga, dan lingkungan. dan sisanya sebesar 67,3\%.

Hasil yang didapatkan dalam penelitian ini sejalan dengan penelitian Munawar dalam Simarmata (2017: 208), yang telah melakukan penelitian di SMA Negeri 14 Medan Siswa kelas $\mathrm{X}$ hasil diperoleh bahwa besarnya kontribusi yang diberikan oleh tingkat pengetahuan terhadap sikap peduli lingkungan siswa adalah sebesar 10,7\% yang kedalam kategori rendah. Sejalan dengan penelitian Munawar dalam Simarmarta, Hasil yang di peroleh dalam penelitian Susanto (2010: 36) yang melakukan penelitian di Desa Sumbersari RW 03 Malang. Dari hasil penelitian menunjukan 38\% memiliki pengetahuan baik, pengetahuan kurang sebesar $36 \%$ dan pengetahuan cukup sebesar 26\%. Menurut peneliti responden yang memiliki pengetahuan kurang disebabkan karena faktor tingkat pendidikan yang mereka tempuh, berdasarkan data umum bahwa pendidikan responden sebagian besar adalah SMA sebesar 42\%, SMP sebesar 24\%, dan SD sebesar 28\%, serta S1 sebesar 6\%. Seperti yang di ungkapkan oleh Kuncoroningrat yang dikutif oleh Nursalam (2003), mengatakan bahwa makin tinggi tingkat pendidikan seseorang makin mudah menerima informasi sehingga makin banyak pula pengetahuan yang dimiliki.

Dengan demikian berdasarkan temuan hasil penelitian secara keseluruhan maka rumusan masalah pada penelitian ini telah terjawab. Hal tersebut menunjukan pula bahwa seberapa besar pengaruh pengetahuan pengelolaan sampah di sekolah terhadap sikap peduli lingkungan siswa SDN Batan Indah. Di karnakan pengetahuan yang di miliki Oleh Siswa tentang Pengetahuan pengelolaan sampah di sekolah sudah sangat mumpuni sehingga informasi serta bimbingan dari sekolah baik dari guru, arahan yang selalu di sampaikan oleh sekolah dan implementasi secara langsung berupa praktek dari pengelolaan sampah yang baik dapat meningkatkan pengetahuan siswa akan pengelolaan sampah dan dapat menerapkannya dalam kehidupan sehari-hari. 


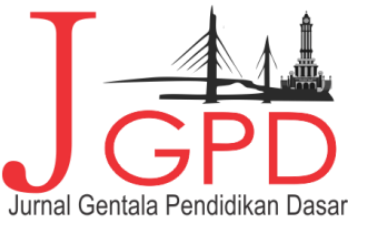

JURNAL GENTALA PENDIDIKAN DASAR Vol.5 №. I Juni 2020, Halaman I-II

P-ISSN : 2614-7092, E-ISSN : 2621-96il

Terbit Online Pada Laman W eb : http://unline-juurnal.unja.ac.id/index.php/gentala email : peny unting.jurnal.g-pgsd回unja.ac.id

\section{KESIMPULAN DAN IMPLIKASI}

Berdasarkan temuan penelitian yang dilakukan di SDN Batan Indah tentang Pengaruh Pengetahuan Pengelolaan Sampah Di Sekolah Terhadap Sikap Peduli Lingkungan Siswa SDN Batan Indah, dapat di simpulkan sebagai berikut :

1. Terdapat korelasi yang kuat. Hal ini dibuktikan dengan hasil uji hipotesis dalam menentukan persamaan regresi, mendapatkan nilai $\mathrm{t}$ hitung $=6,804$ dengan nilai signifikasi sebesar 0,000<0,05, maka Ho ditolak dan Ha diterima. Artinya terdapat pengaruh antara Pengaruh Pengetahuan Pengelolaan Sampah Di Sekolah Terhadap Sikap Peduli Lingkungan Siswa SDN Batan Indah.

2. Besarnya Pengaruh Pengetahuan Pengelolaan Sampah Di Sekolah Terhadap Sikap Peduli Lingkungan Siswa SDN Batan Indah dengan hasil nilai $R$ Square, mendapatkan hasil pengaruh positif tetapi pengaruh tersebut dikatakan kecil atau lemah yaitu sebesar 33,7\%. Hal ini berarti bahwa sekitar 67,3\% sikap peduli lingkungan mungkin dipengaruhi oleh faktor-faktor lain seperti wawasan dan kesadaran, tingkat pendidikan, malas mencari atau berjalan menuju arah tempat sampah, pemahaman dari guru, keluarga, dan lingkungan. Akan tetapi faktor-faktor lain yang $67,3 \%$ itu tidak peneliti teliti.

\section{DAFTAR PUSTAKA}

Boedijono, dkk (2019). Efektifitas Pengelolaan Dana Desa Untuk Pembangunan Dan Pemberdayaan Masyarakat Desa Di Kabupaten Bondowoso. Jurnal Riset Dan Manajemen Bisnis. 4(1): 9-20. Jember: Universitas Jember.

Chan, F (2019). Gerakan Peduli Lingkungan Di Sekolah Dasar. Jurnal Gentala Pendidikan Dasar, 4(2):190-197. Jambi: Universitas Jambi.

Daini, (2017). Pembuatan Standard Operating Procedure (Sop) Pengelolaan Arsip Dinas Kearsipan Dan Perpustakaan Provinsi Sumatera Barat. Jurnal Informasi perpustakaan Dan Kearsipan. 5(1): 238-246.Padang: Universitas Negeri Padang.

Hidayat, (2017). Membudayakan cinta lingkungan kepada siswa melalui garden school. FIP UMJ.

Kes, (2016). Pengelolaan Lingkungan Hidup. Jakarta : Prenadamedia Grup.

Lestari, (2018). Penanaman nilai peduli lingkungan dalam pembelajaran ilmu pengetahuan alam. Jurnal pendidikan ke sd-an. 4(2): 332-337. Universitas Sarjanawiyata Taman Siswa.

Narut, (2019). Analisis Sikap Peduli Lingkungan Pada Siswa Kelas VI Sekolah Dasar di Kota Ruteng. Jurnal Pendidikan dan Kebudayaan. 9(3): 259-266. FKIP Universitas Katolik Indonesia Santu Paulus Ruteng. 

email : peny unting.jurnal.g-pgsd回unja.ac.id

Oktaviani, (2016). Kinerja Dinas Kebersihan, Pertamanan Dan Pemakaman Dalam Pengelolaan Sampah Di Kota Tangerang Selatan. Jurnal ilmu-ilmu social kajian. 27(1): 1-19.

Rizkiyah, (2019). Pengaruh sikap siswa dan pemahaman konsep ekosistem terhadap kepedulian lingkungan. Jurnal ilmiah wahana pendidikan. 5(2):59-68. Jakarta: Universitas Indraprasta PGRI Jakarta.

Siregar dkk, (2018). Buku infografis "menjaga kelestarian lingkungan" untuk menanamkan sikap peduli lingkungan pada anak. Jurnal sisfotek global. 8(2): 40-48. STMIK Bina Sarana Global.

Sejati, (2009). Pengelolaan Sampah Terpadu Dengan System Node, Sub Point, Center Point. Yogyakarta : Kanisius.

Soma, (2010). Pengantar Ilmu Tekhnik Lingkungan (Seri: Pengelolaan Sampah Perkotaan). Bogor : Ipb Press.

Srisanttyorini, (2018). Pengetahuan, sikap dan perilaku ibu rumah tangga terhadap pengelolaan sampah di wilayah sekitar rel kereta api, kelurahan jombang, kecamatan ciputat, kota tangerang selatan. Jurnal kedokteran dan kesehatan. 14(2): 65-73. Tangerang Selatan: Universitas Muhammadiyah Jakarta

Sugiono, (2018). Metode Penelitian Kuantitatif, Kualitatif Dan Rnd. Bandung: Alfabeta Bandung.

Simarmata, (2017). Hubungan Tingkat Pengetahuan Lingkungan Hidup Dengan Sikap Peduli Lingkungan Siswa. Jurnal Pelita Pendidikan. 6(4): 204-210.Medan : Universitas Negeri Medan.

Susanto, (2010), Hubungan Pengetahuan Terhadap Pengelolaan Sampah Organic Dan Non Organik Pada Masyarakat Rw. 03 Sumbersari Malang. Jurnal Keperawatan. 1(1): 3238. Malang : Universitas Muhammadiyah Malang.

Taupiq dkk, (2014). Pengembangan media pembelajaran ipa terpadu berkarakter peduli lingkungan tema "konservasi" berpendekatan science-edutainment. Jurnal pendidikan ipa Indonesia. 3(2): 140-145. Semarang: Universitas Negeri Semarang.

Widodo Susanto, (2009). Kapasitas Masyarakat Dalam Pembinaan Sampah Kota (Studi Masyarakat Jakarta, Tangerang, Bekasi, Depok). Jurnal Teknologi Lingkungan. 10 (3):329-335.

Wulandari, (2014), Tingkat Pengetahuan Ibu Bersalin Tentang Rangsangan Putting Susu Pada Saat Proses Persalinan. Jurnal Edu Health. 4(1): 24-28. Jombang : Universitas Pesantren Tinggi Darul'ulum Jombang. 